\title{
Whole Spine Disc Degeneration Survey according to the Ages and Sex Using Pfirmann Disc Degeneration Grades
}

\section{Chang Hyun $\mathrm{Oh}^{1}$, Seung Hwan Yoon ${ }^{2}$}

${ }^{1}$ Department of Neurosurgery, Guri Cham Teun Teun Hospital, Guri, ${ }^{2}$ Department of Neurosurgery, Inha University Hospital, Inha University College of Medicine, Incheon, Korea

Corresponding Author:

Seung Hwan Yoon

Department of Neurosurgery, Inha University Hospital, Inha University College of Medicine, 27 Inhang-ro, Jung-gu, Incheon 22332, Korea

Tel: $+82-32-890-2370$

Fax: +82-32-890-2374

E-mail: nsyoon@gmail.com

Received: February 10, 2017 Revised: December 19, 2017 Accepted: December 26, 2017
Copyright () 2017 by The Korean Spinal Neurosurgery Society

This is an open access article distributed under the terms of the Creative Commons Attribution Non-Commercial License (http://creativecommons.org/licenses/bync/4.0/) which permits unrestricted noncommercial use, distribution, and reproduction in any medium, provided the original work is properly cited.

Objective: Pfirrmann disc grade is a useful scoring tool for evaluating disc degeneration, but normal values according to aging process has not been elucidated. This study was conducted to identify the prevalence and pattern of whole spine disc degeneration according to ages and gender differences.

Methods: Total 653 patients (336 male and 317 female patients, $48.1 \pm 58.7$ years old) who took whole spine magnetic resonance images were enrolled in this study. There were 19 cases in their 2nd decades and 74 cases in 3rd decades, 141 cases in 4th decades, 129 cases in 5th decades, 139 cases in 6th decades, and 93 cases in 7th decades, 58 cases in over 8th decades. Pfirmann disc grades were measured according to sex and ages by 2 neurosurgeons that were blind to this study.

Results: All spinal disc degeneration grades were correlated with ageing. The Pfirmann disc grades of degeneration in all spine levels showed the statistically significant difference according to the ages $(p<0.001)$. The common Pfirmann disc grades according to the ages were grade 3 among 2 nd to 5 th decades, and grade 4 was more common than 6 th decades. The lower cervical level (C2-3 to C4-5) and lumbar level (L1-2 to L5-S1) were happened relatively early severe disc degeneration compared to other levels. The intersexual differences were increased after 6th decades.

Conclusion: Disc degeneration is natural course after one's 2nd decades. And its incidence and grade were increased with age, and more affected by sexual difference after 6th decades.

Key Words: Pfirmann disc grades, Disc degeneration, Spine, Age, Decades

\section{INTRODUCTION}

Disc degeneration in modern humans is often attributed to our upright, bipedal locomotion that is thought to place huge mechanical stresses on the vertebral column. Interestingly, in the analyze of the 1.5 -million-year-old boy Homo erectus who died at an age of approximately 8 years, the indirect evidence of possible juvenile disc herniation (disc degeneration) represents the earliest known case of this typical human ailment that is intricately linked to upright bipedalism ${ }^{14)}$. Nowadays, disc degeneration is a leading cause of lower back pain and a significant societal and economic problem world widely, and its prevalence are increasing due to the gradually lifestyle changes and the increased the lifespan in the modern civilized society compared to the previous period ${ }^{10)}$. In fact, the relationship between ageing and disc degeneration is a matter of natural course, but, the comparison study for disc degeneration on imaging studies and ageing were relatively not well reported in the literature. Therefore, the authors conducted this study to identify the natural course of whole spine disc degeneration, and standard disc degeneration grade according to the ages.

\section{MATERIALS AND METHODS}

Total of all 653 patients who took whole spine magnetic resonance (MR) images between November 2012 and January 2013 at single spine institution were entrolled in this study to get permission of Institutional Review Board in Inha University Hospital (3190493AN01-201210HR-003). The exclusion criteria for this study were lumbosacral abnormalities such as lumbarization or sacralization of the lumbosacral junction. The mean age was 48.1 \pm 58.7 years old (range, 12-95 years), and the subjects were composed with 336 male and 317 female patients. There were 19 cases in their 2 nd decades and 74 cases in 3rd decades, 141 cases in 4th decades, 129 cases in 5th decades, 139 cases in 6th decades, and 93 cases in 7 th decades, 58 cases in over 8th decades.

Whole spine disc degenerations were graded 
by 2 neurosurgeons that were blind to this study using the Pfirrmann classification (Fig. 1) ${ }^{23,24)}$. If the measured grades were differently checked depending on different physicians, the grades were rechecked, and the agreed grades by 2 observers were selected. The Pfirrmann classification is one of useful tool to assess the degree of disc degeneration from T2-weighted images as it summarized in Table 1: grade 1, normal shape, no horizontal bands, clear distinction of nucleus and annulus; grade 2, nonho-

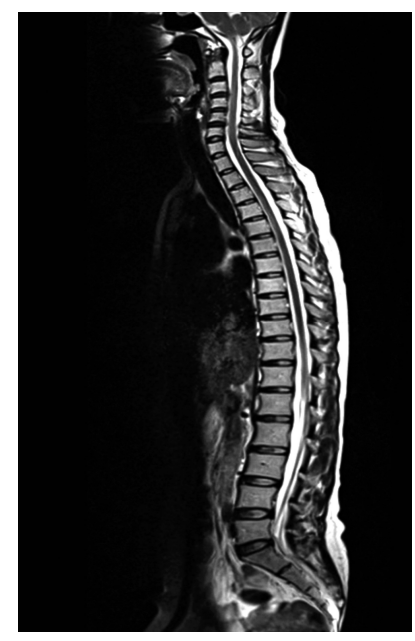

Fig. 1. Whole spine sagittal T2weighted image was analyzed to check the Pfirrmann disc grade. mogeneous shape with horizontal bands, some blurring between nucleus and annulus; grade 3, nonhomogeneous shape with blurring between nucleus and annulus, annulus shape still recognizable; grade 4, nonhomogeneous shape with hypointensity, annulus shape not intact and distinction between nucleus and annulus impossible, disc height usually decreased; and grade 5, same as grade 4 but with collapsed disc space. Grades 1 to 2 were classified as normal discs, while grades 3 to 5 were defined as degenerated $^{17,23,27}$. All MR examinations were performed by 1.5 Tesla MR System (Magnetom Essenza M-1.5-S, Siemens, Munich, Germany), and only the sagittal T2-weighted image in whole spine MR were included in this analysis.

The Pfirrmann disc grades according to all disc levels from C2-3 to L5-S1 of 653 patients were analyzed including the sex and age variables, so total 15,019 disc levels were included in this study. The Levene test for equality of variances, Spearman rank correlation coefficient test and Mann-whitney $U$ analysis were used to determine the significances of differences between age or sex and disc degeneration. SPSS ver. 15.0 (SPSS Inc., Chicago, IL, USA) was used throughout, and statistical significance was accepted for p-values of $<0.050$.

\section{RESULTS}

Intraclass correlation between 2 different observers was found
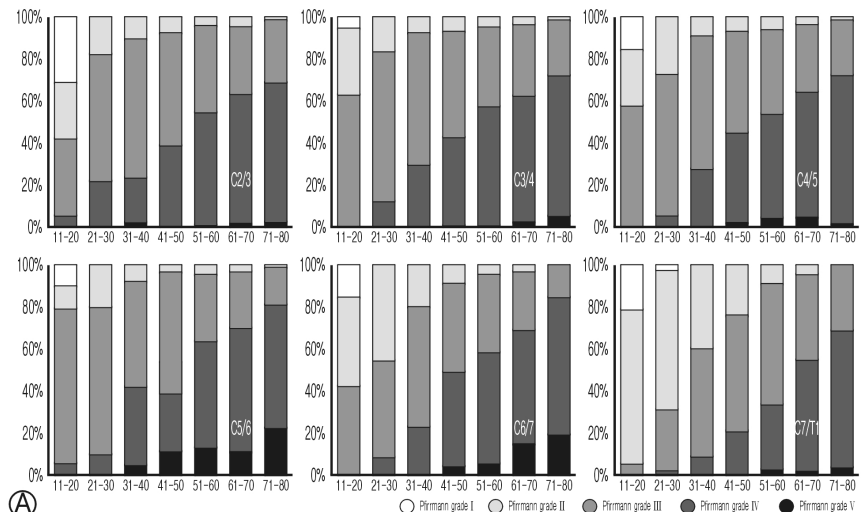

(A)
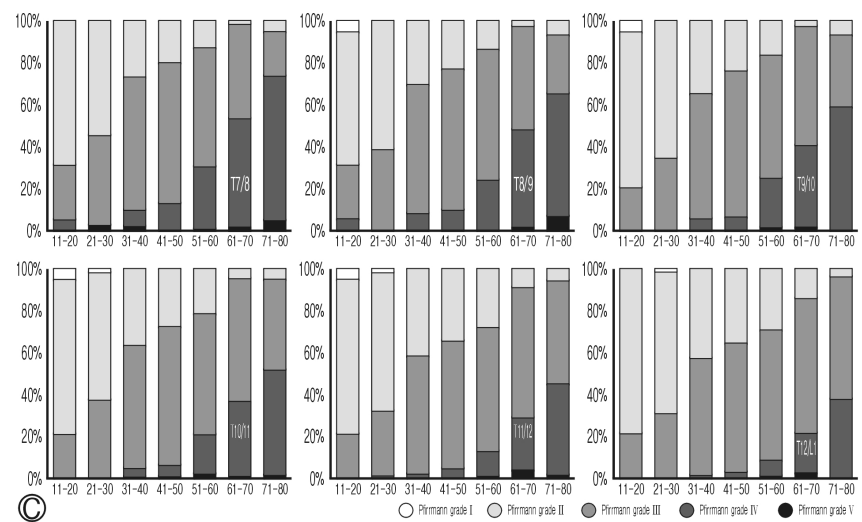
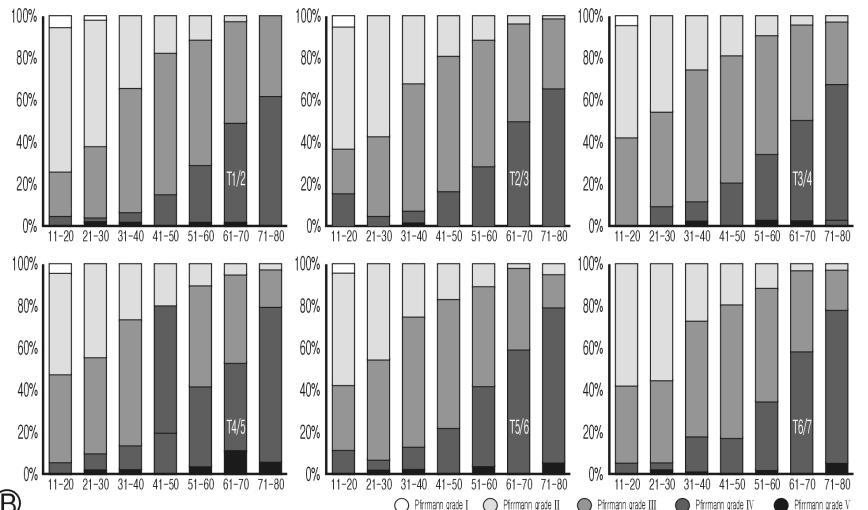

(B)
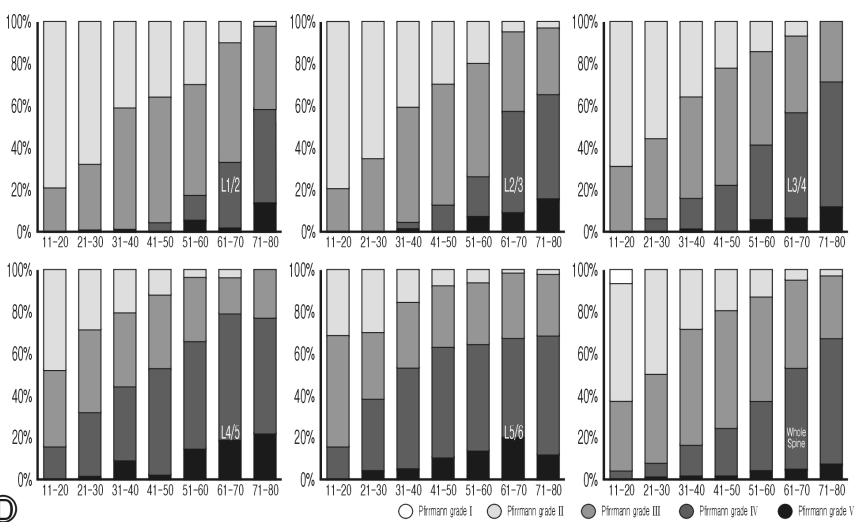

Fig. 2. Pfirrmann grade distribution by age at cervical (A), thoracic (B, C), lumbar levels and whole spine (D). 
Table 1. The classification of Pfirrmann disc degeneration grade

\begin{tabular}{|c|c|c|c|c|}
\hline Grade & Structure & $\begin{array}{l}\text { Distinction of nucleus } \\
\text { and anulus }\end{array}$ & Signal intensity & Height of Intervertebral disc \\
\hline 1 & Homogeneous, bright white & Clear & $\begin{array}{l}\text { Hyperintense, isointense to } \\
\text { cerebrospinal fluid }\end{array}$ & Normal \\
\hline 3 & Inhomogeneous, gray & Unclear & Intermediate & Normal to slightly decreased \\
\hline
\end{tabular}

Grade 1, normal shape, no horizontal bands, clear distinction of nucleus and annulus; grade 2, nonhomogeneous shape with horizontal bands, some blurring between nucleus and annulus; grade 3, nonhomogeneous shape with blurring between nucleus and annulus, annulus shape still recognizable; grade 4, nonhomogeneous shape with hypointensity, annulus shape not intact and distinction between nucleus and annulus impossible, disc height usually decreased; grade 5, same as grade 4 but with collapsed disc space.

to be 0.891 . In the Levene test for equality of variances, the equal variance of disc degeneration was observed according age in both male and female group $(\mathrm{p}=0.487)$, and the distribution was also not different between 2 groups ( $\mathrm{p}=0.170)$. All checked Pfirrmann grades of disc degeneration at each disc levels were summarized in Table 2. The mean age was $48.1 \pm 58.7$ years old (range, $12-$ 95 years), and the subjects were composed with 336 male and 317 female patients. The most common Pfirrmann disc grades of disc degeneration without regarding of age was Pfirrmann disc grade 3 (45.5\%, 1,782 among 3,918 discs) following Pfirmann disc grade 4 (38.7\%, 1,517 among 3,918 discs) and grade 3 (11.9\%, 468 among 3,918 discs) in cervical regions, Pfirrmann disc grade 3 (52.5\%, 4,115 among 7,836 discs) following Pfirrmann disc grade 2 (24.3\%, 1,901 among 7,836 discs) and grade 4 (22.0\%, 1,727 among 3,918 discs) in thoracic regions, and Pfirrmann disc grade 3 (40.6\%, 1,327 among 3,265 discs) following Pfirrmann disc grade 4 (30.7\%, 1,002 among 3,265 discs) and grade $3(22.4 \%, 732$ among 3,265 discs) in lumbar regions.

All spinal disc degeneration grades were correlated with ageing with the analysis using Spearmann rank correlation coefficient test. In this study, there were 19 cases in their 2 nd decades and 74 cases in 3rd decades, 141 cases in 4th decades, 129 cases in 5th decades, 139 cases in 6th decades, and 93 cases in 7th decades, 58 cases in over 8th decades (Fig. 2). The Pfirrmann disc grades of degeneration in all spine levels showed the statistically significant difference according to the ages $(p<0.001)$, and these were gradually increased from grade 1 to 5 with ageing process. The common Pfirrmann disc grades according to the ages were Grade 3 among 2 nd to 5 th decades and grade 4 was more common than 6 th decades. The lower cervical level (from C5-6 to C6-7) and lumbar level (from L1-2 to L5-S1) were showed relatively high percentage of severe disc degeneration (Pfirrmann disc grade 5) in early stage (from 5th decades) compared to high cervical level (from $\mathrm{C} 2-3$ to $\mathrm{C} 4-5$ ) and thoracic level (from C7-T1 to T12-L1). Indeed, all single level disc degeneration at each level was significantly correlated with other disc degeneration at the different disc level in the analysis using Spearman rank correlation test $(\mathrm{p}<0.001)$.

The relation between sex and Pfirrmann disc grade was ana-
Table 2. All Pfirrmann grades of disc degeneration at each disc levels

\begin{tabular}{|c|c|c|c|c|c|}
\hline \multirow{2}{*}{ Level } & \multicolumn{5}{|c|}{ Grade } \\
\hline & 1 & 2 & 3 & 4 & 5 \\
\hline C2-3 & $6(0.9)$ & $54(8.3)$ & $318(48.7)$ & $269(41.2)$ & $6(0.9)$ \\
\hline C3-4 & $1(0.2)$ & $49(7.5)$ & $317(48.5)$ & $279(42.7)$ & $7(1.1)$ \\
\hline C4-5 & $3(0.5)$ & $60(9.2)$ & $312(47.8)$ & $265(40.6)$ & $13(2.0)$ \\
\hline C5-6 & $2(0.3)$ & $45(6.9)$ & $270(41.3)$ & $275(42.1)$ & $61(9.3)$ \\
\hline C6-7 & $3(0.5)$ & $93(14.2)$ & $262(40.1)$ & $259(39.7)$ & $36(5.5)$ \\
\hline C7-T1 & $6(0.9)$ & 167 (25.6) & $303(46.4)$ & $170(26.0)$ & $7(1.1)$ \\
\hline T1-2 & $2(0.3)$ & $148(22.7)$ & $346(53.0)$ & $150(23.0)$ & $7(1.1)$ \\
\hline $\mathrm{T} 2-3$ & $1(0.2)$ & $144(22.1)$ & $344(52.7)$ & $161(24.7)$ & $3(0.5)$ \\
\hline T3-4 & $1(0.2)$ & $126(19.3)$ & $340(52.1)$ & $179(27.4)$ & $7(1.1)$ \\
\hline T4-5 & $1(0.2)$ & $128(19.6)$ & $319(48.9)$ & $193(29.6)$ & $12(1.8)$ \\
\hline T5-6 & $1(0.2)$ & $125(19.1)$ & $315(48.2)$ & $201(30.8)$ & $11(1.7)$ \\
\hline T6-7 & $0(0)$ & $139(21.3)$ & $315(48.2)$ & $192(29.4)$ & $7(1.1)$ \\
\hline T7-8 & $0(0)$ & $139(21.3)$ & $344(52.7)$ & $161(24.7)$ & $3(0.5)$ \\
\hline T8-9 & $1(0.2)$ & $155(23.7)$ & $354(54.2)$ & $137(21.0)$ & $5(0.8)$ \\
\hline T9-10 & $1(0.2)$ & $170(26.0)$ & $359(55.0)$ & $120(18.4)$ & 7 (1.1) \\
\hline T10-11 & $2(0.3)$ & $184(28.2)$ & $359(55.0)$ & $101(15.5)$ & $3(0.5)$ \\
\hline T11-12 & $2(0.3)$ & $216(33.1)$ & $354(54.2)$ & 76 (11.6) & $6(0.9)$ \\
\hline T12-L1 & $1(0.2)$ & $227(34.8)$ & $366(56.0)$ & $56(8.6)$ & $9(1.4)$ \\
\hline L1-2 & $0(0)$ & $222(34.0)$ & $333(31.0)$ & 78 (11.9) & $20(3.1)$ \\
\hline L2-3 & $0(0)$ & 197 (29.7) & $307(47.0)$ & $122(18.7)$ & $30(4.6)$ \\
\hline L3-4 & $0(0)$ & $160(24.5)$ & $284(43.5)$ & $187(28.6)$ & $22(3.4)$ \\
\hline L4-5 & $0(0)$ & $82(12.6)$ & $202(30.9)$ & $302(46.2)$ & $67(10.3)$ \\
\hline L5-S1 & $0(0)$ & $71(10.9)$ & $201(30.8)$ & 313 (47.9) & 68 (10.4) \\
\hline
\end{tabular}

Values are presented as number (\%)

Grade 1, normal shape, no horizontal bands, clear distinction of nucleus and annulus; grade 2, nonhomogeneous shape with horizontal bands, some blurring between nucleus and annulus; grade 3, nonhomogeneous shape with blurring between nucleus and annulus, annulus shape still recognizable; grade 4 , nonhomogeneous shape with hypointensity, annulus shape not intact and distinction between nucleus and annulus impossible, disc height usually decreased; grade 5 , same as grade 4 but with collapsed disc space.

lyzed by Mann-Whitney U-test (Table 3); it showed that no dif- 
ferent disc degeneration among female population in all spine level with only except of the level of $\mathrm{C} 2-3(\mathrm{p}=0.046), \mathrm{T} 6-7$ ( $\mathrm{p}=$ $0.050)$ and L4 $5(\mathrm{p}=0.008)$. The composition of mild (Pfirrmann disc grades 1-2), moderate (Pfirrmann disc grade 3 ) and severe disc degeneration (Pfirrmann disc grades $4-5$ ) is differently checked at all ages (Fig. 3). The intersexual difference were not definite until the 5 th decades (significant differences were observed at the level of $\mathrm{C} 3 / 4$ and L5/S1 in 3rd decade, and L4/5 in 5th decade), but, the differences were frequently observed after one's 6th decades (Fig. 4; significant differences were observed at the level of T8/9, T9/10, T12/L1, L1/2, L2/3, and L3/4 in 6th decade, T6/7 and T7/8 in 7th decade, and T6/7, T9/10, T10/11, and T11/12 in after 8th decade).

\section{DISCUSSION}

Intervertebral discs are complex anatomical structures that are essential for the mobility of intervertebral joints, and also participate in anchoring vertebrae together and distributing the pressure that results from movement of the entire trunk ${ }^{6}$. The first signs of disc degeneration begin to appear upon skeletal maturity in the nucleus pulposus ${ }^{3,6)}$. Up until this time, 2 cell types populate the nucleus pulposus; chondrocyte-like cells and notochordal cells, and notochordal cells are responsible for maintaining homeostasis ${ }^{1,7-9)}$. The loss of these cells during skeletal maturation might constitute one of the first changes that occur in the cascade of degenerative events. Although this degeneration arises during the natural aging process, pathological degeneration can also occur, which progresses in an accelerated and brutal manner ${ }^{6}$.

Pfirrmann disc degeneration (PfDD) grade I-II

$\square$ (PfDD) grade III

(PfDD) grade IV-V
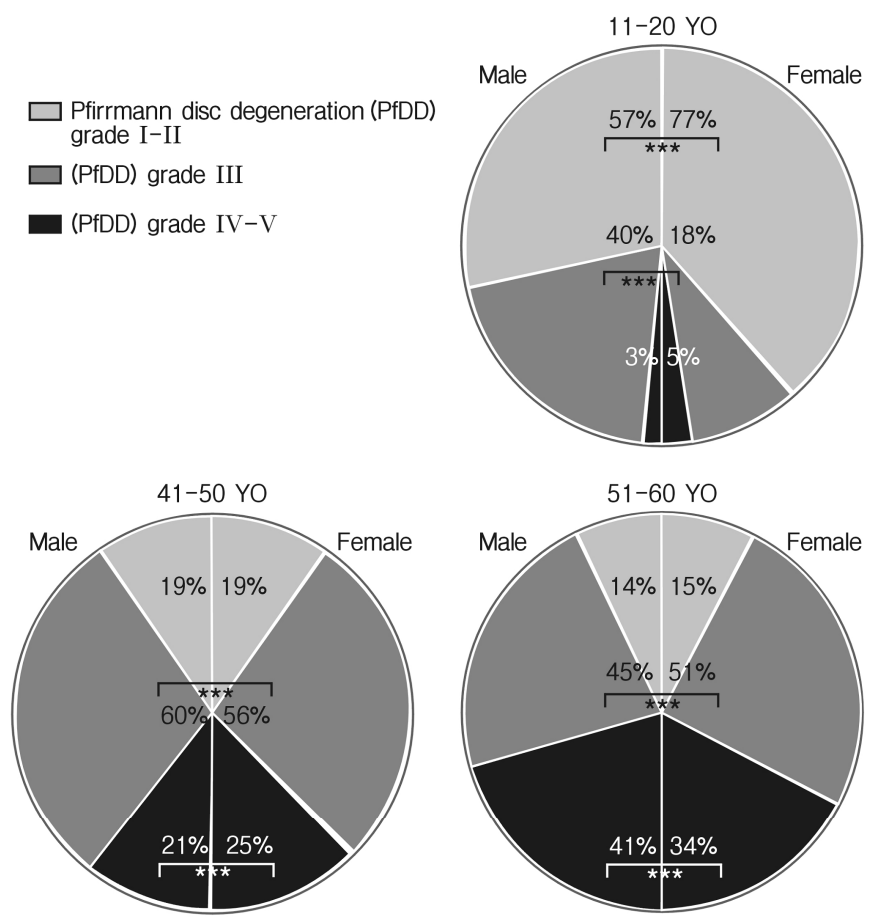

Fig. 3. Pfirrmann grade distribution (PfDD) by sex. YO, years old. ${ }^{* * *}$ indicated statistically significant difference.
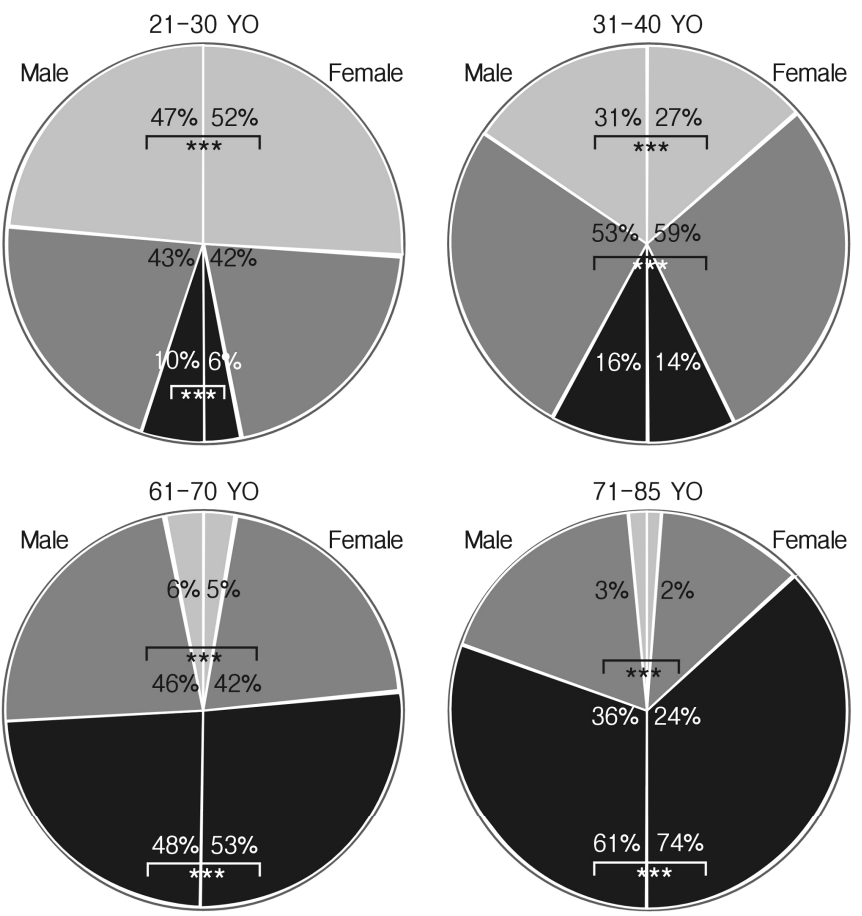

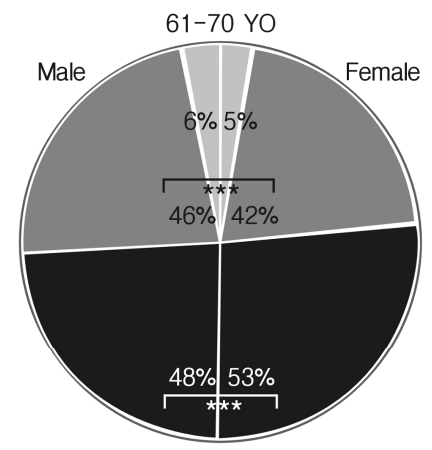

Table 3. Comparison of Pfirrmann degeneration between sexes at each disc level in all age decades

\begin{tabular}{|c|c|}
\hline $\begin{array}{l}\text { Level } \\
\end{array}$ & p-value* \\
\hline $\mathrm{C} 2-3$ & 0.046 \\
\hline C3-4 & 0.782 \\
\hline C4-5 & 0.349 \\
\hline C5-6 & 0.667 \\
\hline C6-7 & 0.678 \\
\hline C7-T1 & 0.742 \\
\hline T1-2 & 0.665 \\
\hline $\mathrm{T} 2-3$ & 0.987 \\
\hline T3-4 & 0.787 \\
\hline T4-5 & 0.639 \\
\hline T5-6 & 0.084 \\
\hline T6-7 & 0.050 \\
\hline T7-8 & 0.316 \\
\hline T8-9 & 0.835 \\
\hline T9-10 & 0.268 \\
\hline T10-11 & 0.139 \\
\hline T11-12 & 0.278 \\
\hline T12-L1 & 0.358 \\
\hline L1-2 & 0.783 \\
\hline L2-3 & 0.315 \\
\hline L3-4 & 0.713 \\
\hline L4-5 & 0.008 \\
\hline L5-S1 & 0.179 \\
\hline
\end{tabular}

*Mann-Whitney U-test 

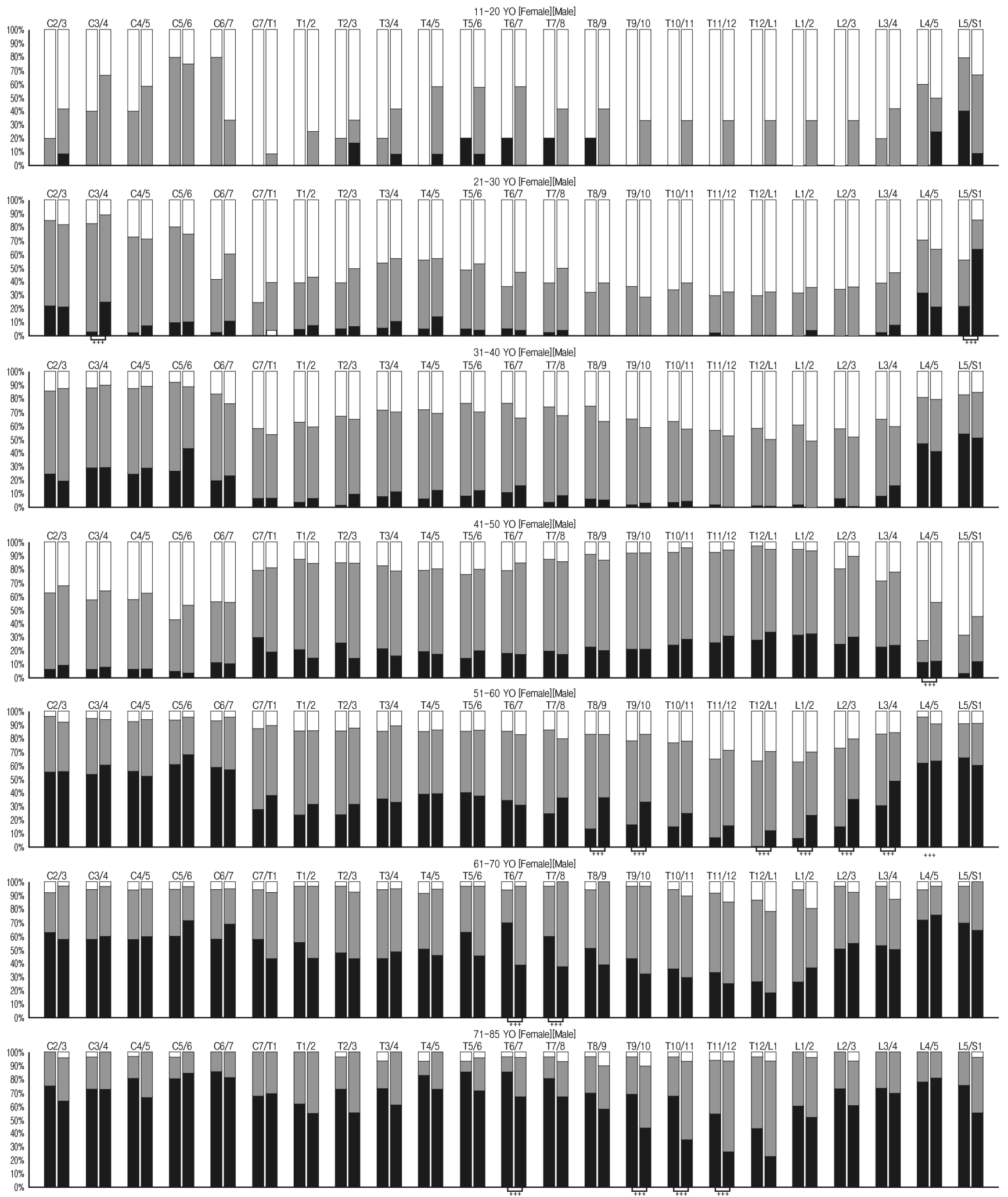

Fig. 4. Pfirrmann grade distribution by sex and age. YO, years old. ${ }^{* * *}$ indicated statistically significant difference. 
Back pain is strongly associated with disc degeneration and neurological dysfunction ${ }^{2028)}$, and is one of the leading chronic illnesses requiring physician care and utilization of the healthcare system $^{4,11)}$. Disc degeneration has been attributed to elevation in cytokine levels in the disc, which in turn elevates levels of aggrecanases and all matrix metalloproteinases that cleave aggrecan and other matrix components ${ }^{2}$. Fragmentation and loss of aggrecan, the most abundant proteoglycan present in the disc, results in loss of disc height, and its neurological sequelae lead to back pain ${ }^{5,25,26)}$. The intervertebral disc becomes avascular by the fourth year of life, and it has been the major target of basic and clinical research on low back pain ${ }^{28)}$. Despite the efficiency of pain-relieving treatments, the physicians had been seeked to develop innovative therapeutic approaches that might limit the use of invasive surgical procedures ${ }^{6}$. But, before a prerequisite to the development of these strategies, we should improve our fundamental knowledge regarding disc degeneration pathophysiology and its natural course.

Degenerative disc disease is part of the natural process of growing older, although it also can be caused by injury or trauma ${ }^{18)}$. Indeed, recently, its relative other risk factors such as biomechanical $^{18)}$, biochemical ${ }^{21)}$, genetic ${ }^{15)}$, occupational ${ }^{29)}$ disc nutritional factors ${ }^{12}$, were investigated and identified. Although definite answer for disc degeneration was not established yet, it was considered that ageing is a main pathogenesis of disc degeneration associated with multifactorial influence as our result indicated. In this study, the authors divided the cases according to the one's decades of life, and the Pfirrmann disc grades in all spine levels showed that gradually of disc degeneration with ageing process. The common Pfirrmann disc grades were grade 3 in 2 nd to 5 th decades, and grade 4 was more common in over 6 th decades. And it is well correlated with the data of previous systemic reviews ${ }^{13,18)}$.

The Pfirrmann disc grades of degeneration in all spine levels showed the significant difference according to the ages, and all single level disc degeneration at each level was significantly correlated with other disc degeneration at the different disc level. This result was similar to previous study which reported a higher prevalence of disc degeneration of the cervical spine in patients with lumbar disc herniation compare to healthy volunteers ${ }^{22}$. In the consecutive studies about cervical and lumbar degeneration among asymptomatic Korean subjects, there are some similar result were observed: (1) high prevalence of annular fissure, nucleus degeneration, and extrusion at cervical and lumbar in asymptomatic subjects ${ }^{16,19)}$; (2) high prevalence of bulging, protrusion, and annular fissure at L4/5 and L5/S1 and nucleus degeneration at $\mathrm{L} 5 / \mathrm{S} 1$ in young ages ${ }^{16}$; and (3) close relationship between the cervical degeneration and lumbar degeneration ${ }^{19)}$. Hence, the results of these studies suggest that disc degeneration appears to be a systemic phenomenon. And, it was showed that no different disc degeneration in all spine level between sexes (summarized all aging decades) with some exception of the level of $\mathrm{C} 2-3, \mathrm{~T} 6-7$, and $\mathrm{L} 4-5$. This result was very similar to previous studies ${ }^{18,22}$, but each segment analysis with age and sex consideration showed that sexual difference according to the decades. The intersexual difference were not definite until the 5 th decades (except at the level of C3/4, L5/S1, and L4/5), but, the differences were frequently observed after one's 6th decades (especially at the level of T6/7-L3/4).

Some limitations could interfere this result. First, the Pfirrmann disc grades could over or underestimated by using whole spine MR image, because the image were could differently checkable by different image voxel size. Second, this study was based on the population who visited the hospital with neck or backpain, so this result is not indicated the normal value of healthy population. Nevertheless these limitations, this recent study provided useful information about the natural course of whole spine disc degeneration, and standard disc degeneration grade according to the ages. In the near future, the authors considered that largescale and well-designed studies are required reviewing the topic of disc degeneration.

\section{CONCLUSION}

As a conclusion, disc degeneration is natural course after one's 2nd decades, and its incidence and grade were increased with age. Disc degeneration affected by sexual difference was focused in the motional segments such as C3/4, L4/5, and L5/S1 until 5 th decades, and it changed to the thoracic segments after 6th decades.

\section{CONFLICT OF INTEREST}

No potential conflict of interest relevant to this article was reported.

\section{REFERENCES}

1. Aguiar DJ, Johnson SL, Oegema TR: Notochordal cells interact with nucleus pulposus cells: regulation of proteoglycan synthesis. Exp Cell Res 246:129-137, 1999

2. Akyol S, Eraslan BS, Etyemez H, Tanriverdi T, Hanci M: Catabolic cytokine expressions in patients with degenerative disc disease. Turk Neurosurg 20:492-499, 2010

3. Boos N, Weissbach S, Rohrbach H, Weiler C, Spratt KF, Nerlich AG: Classification of age-related changes in lumbar intervertebral discs: 2002 Volvo Award in basic science. Spine (Phila Pa 1976) 27:2631-2644, 2002

4. Cats-Baril WL, Frymoyer JW: Identifying patients at risk of becoming disabled because of low-back pain. The Vermont Rehabilitation Engineering Center predictive model. Spine (Phila Pa 1976) 16:605-607, 1991

5. Chung SA, Khan SN, Diwan AD: The molecular basis of intervertebral disk degeneration. Orthop Clin North Am 34:209-219, 2003

6. Colombier P, Clouet J, Hamel O, Lescaudron L, Guicheux J: The lumbar intervertebral disc: from embryonic development to degeneration. Joint Bone Spine 81:125-129, 2014

7. Erwin WM: The Notochord, Notochordal cell and CTGF/CCN-2: ongoing activity from development through maturation. J Cell Commun Signal 2:59-65, 2008 
8. Erwin WM, Ashman K, O'Donnel P, Inman RD: Nucleus pulposus notochord cells secrete connective tissue growth factor and up-regulate proteoglycan expression by intervertebral disc chondrocytes. Arthritis Rheum 54:3859-3867, 2006

9. Erwin WM, Islam D, Inman RD, Fehlings MG, Tsui FW: Notochordal cells protect nucleus pulposus cells from degradation and apoptosis: implications for the mechanisms of intervertebral disc degeneration. Arthritis Res Ther 13:R215, 2011

10. Frith JE, Cameron AR, Menzies DJ, Ghosh P, Whitehead DL, Gronthos $\mathrm{S}$, et al: An injectable hydrogel incorporating mesenchymal precursor cells and pentosan polysulphate for intervertebral disc regeneration. Biomaterials 34:9430-9440, 2013

11. Gawri R, Antoniou J, Ouellet J, Awwad W, Steffen T, Roughley P, et al: Best paper NASS 2013: link-N can stimulate proteoglycan synthesis in the degenerated human intervertebral discs. Eur Cell Mater 26:107-119, 2013

12. Grunhagen T, Shirazi-Adl A, Fairbank JC, Urban JP: Intervertebral disk nutrition: a review of factors influencing concentrations of nutrients and metabolites. Orthop Clin North Am 42:465-477, vii, 2011

13. Hadjipavlou AG, Tzermiadianos MN, Bogduk N, Zindrick MR: The pathophysiology of disc degeneration: a critical review. J Bone Joint Surg Br 90:1261-1270, 2008

14. Haeusler M, Schiess R, Boeni T: Evidence for juvenile disc herniation in a homo erectus boy skeleton. Spine (Phila Pa 1976) 38:E123128, 2013

15. Kao PY, Chan D, Samartzis D, Sham PC, Song YQ: Genetics of lumbar disk degeneration: technology, study designs, and risk factors. Orthop Clin North Am 42:479-486, vii, 2011

16. Kim SJ, Lee TH, Lim SM: Prevalence of disc degeneration in asymptomatic korean subjects. Part 1: lumbar spine. J Korean Neurosurg Soc 53:31-38, 2013

17. Kim SJ, Lee TH, Yi S: Prevalence of disc degeneration in asymptomatic korean subjects. Part 3: cervical and lumbar relationship. J Korean Neurosurg Soc 53:167-173, 2013

18. Lee MJ, Dettori JR, Standaert CJ, Brodt ED, Chapman JR: The natural history of degeneration of the lumbar and cervical spines: a systematic review. Spine (Phila Pa 1976) 37(22 Suppl):S18-30, 2012
19. Lee TH, Kim SJ, Lim SM: Prevalence of disc degeneration in asymptomatic Korean subjects. Part 2: cervical spine. J Korean Neurosurg Soc 53:89-95, 2013

20. Luoma K, Riihimäki H, Luukkonen R, Raininko R, Viikari-Juntura E, Lamminen A: Low back pain in relation to lumbar disc degeneration. Spine (Phila Pa 1976) 25:487-492, 2000

21. Ohshima H, Urban JP: The effect of lactate and $\mathrm{pH}$ on proteoglycan and protein synthesis rates in the intervertebral disc. Spine (Phila Pa 1976) 17:1079-1082, 1992

22. Okada E, Matsumoto M, Fujiwara H, Toyama Y: Disc degeneration of cervical spine on MRI in patients with lumbar disc herniation: comparison study with asymptomatic volunteers. Eur Spine J 20:585-591, 2011

23. Pfirrmann CW, Metzdorf A, Zanetti M, Hodler J, Boos N: Magnetic resonance classification of lumbar intervertebral disc degeneration. Spine (Phila Pa 1976) 26:1873-1878, 2001

24. Rim DC: Quantitative Pfirrmann disc degeneration grading system to overcome the limitation of Pfirrmann disc degeneration grade. Korean J Spine 13:1-8, 2016

25. Roughley PJ: Biology of intervertebral disc aging and degeneration: involvement of the extracellular matrix. Spine (Phila Pa 1976) 29:2691-2699, 2004

26. Roughley PJ, Melching LI, Heathfield TF, Pearce RH, Mort JS: The structure and degradation of aggrecan in human intervertebral disc. Eur Spine J 15 Suppl 3:S326-332, 2006

27. Takatalo J, Karppinen J, Taimela S, Niinimäki J, Laitinen J, Sequeiros RB, et al: Association of abdominal obesity with lumbar disc degeneration--a magnetic resonance imaging study. PLoS One 8: e56244, 2013

28. Takeno K, Kobayashi S, Negoro K, Uchida K, Miyazaki T, Yayama $\mathrm{T}$, et al: Physical limitations to tissue engineering of intervertebral disc cells: effect of extracellular osmotic change on glycosaminoglycan production and cell metabolism. Laboratory investigation. J Neurosurg Spine 7:637-644, 2007

29. Williams FM, Sambrook PN: Neck and back pain and intervertebral disc degeneration: role of occupational factors. Best Pract Res Clin Rheumatol 25:69-79, 2011 